\title{
The Upsurge of Islamist Violence in the North Caucasus: Exploring the Case Studies of Dagestan and Kabardino-Balkaria
}

\author{
By Emil Souleimanov*
}

Recent years have seen an increase in subversive activities emanating from the North Caucasus-based Islamist insurgents who seek to establish an independent Islamic theocracy on the southwestern-most fringe of Russia, a volatile region predominantly inhabited by Muslim ethnic subgroups. ${ }^{1}$ In fact, according to official Russian sources, the frequency of terrorist attacks in the region increased by 60 percent from 2008 to $2009^{2}$ - that is, the very same year that president Dmitry Medvedev announced the formal end of the virtually decade-long anti-terrorist operation in the breakaway province of Chechnya. In 2010, this virulent trend continued further, with attacks resulting in the deaths of 151 people and injuries to 656 others, nearly doubling the previous year's account of 92 killed and 332 wounded. $^{3}$

While there has been a recent decline in the levels of violence in Chechnya and Ingushetia, the situation has been further deteriorating in Kabardino-Balkaria and Dagestan, Russia's autonomous ethnic areas in the North Caucasus region. Indeed, according to recent estimates, the rate of violent acts carried out by members of the Caucasus Emirate or groups of militants associating themselves with the ongoing

Emil Souleimanov holds his LL.M. from Saint Petersburg State Technical University, Russia, and his M.A. and PhD. in International Relations from Charles University in Prague. He is currently an assistant professor in the Department of Russian and East European Studies at Charles University. He is the author of An Endless War: The Russian-Chechen Conflict in Perspective (Peter Lang, 2007) and of numerous research articles dealing with the security situation in the Caucasus, Turkey, and Iran. This article is based on earlier versions, titled "Dagestan: The Emerging Core of the North Caucasus Insurgency" and "Kabardino-Balkaria Risks Becoming New Insurgency Hotspot," both published in the Johns Hopkins Central Asia and Caucasus Analyst, on 29 August 2010 and 2 March 2011, respectively.

1 Nowadays, the members of all native North Caucasian ethnicities and around a quarter of North Ossetians adhere to Sunni Islam; the remainder of the North Ossetian population and a marginal portion of Kabardeys from the town of Mozdok profess Orthodox Christianity.

2 "Ugroza terrorizma v Rossii sokhranaetsya" ["The Terrorist Threat in Russia Remains"], Rosbalt (21 February 2010); available at http://www.rosbalt.ru/style/2010/02/21/714695. html.

3 "Genprokuror predlozhil zashishatsya ot terraktov samim" ["The Chief Executor has Proposed to Defend from Terrorist Attacks by Ourselves"], BBC.com (Russian version) (27 April 2001); available at http://www.bbc.co.uk/russian/russia/2011/04/110427_chaika_speech_terror.shtml. 
Islamist insurgency increased 242 percent in Kabardino-Balkaria and 63 percent in Dagestan in 2010 in comparison to the previous year. Simultaneously, the number of terrorist and diversionary attacks in the neighboring republics of Chechnya and Ingushetia has dropped by 37 and 54 percent, respectively, over the same period. ${ }^{4}$

Just to mention few particularly salient examples: on 4 September 2010, Dagestan's Minister for National Affairs, Bekmurza Bekmurzayev, was assassinated. The next day, the Russian military base at Buynaksk was attacked by a suicide bomber, claiming the lives of four federal soldiers. Shootings, bombings, and police raids against the strongholds of Islamist insurgents occur on a daily basis, and have become an integral part of the political landscape of this mountainous republic. In February 2011 , three Russian tourists were killed in the mountainous Elbrus area of KabardinoBalkaria by local Islamist insurgents, with two others escaping with serious injuries. Since Fall 2010, a series of audacious attacks has been carried out by insurgents in Kabardino-Balkaria, claiming the lives of the republic's mufti, Anas Pshikhachev; a prominent Kabardey ethnologist, Aslan Tsipinov; and a number of police officers and state officials. Indeed, recent events have contributed to Kabardino-Balkaria becoming one of the major hotspots of the North Caucasian insurgency, along with Dagestan, turning these two mountainous republics into scenes of de facto civil war. This article is an attempt to explain the reasons behind the recent developments in Dagestan and Kabardino-Balkaria that have led to the regions becoming centers of the Islamist insurgent movement in the North Caucasus.

\section{Dagestan}

The most populous autonomous republic of Russia's North Caucasus region, with 2.5 million inhabitants, Dagestan is situated in the Northeast Caucasus on the shores of the Caspian Sea. It has historically been one of the most traditionalist areas of the former USSR, along with Central Asia's Fergana Valley. Alongside neighboring Chechnya and Ingushetia, the custom of blood feud is still commonplace in Dagestan, whose ethnic groups are broken down into competing clans. Local customary law (adat) still plays an important role, especially in the highly isolated mountainous areas in the south, center, and west of the country. Accordingly, Dagestani society lives in accordance with the patriarchal code of honor, where the main virtue of an unwed female consists in her purity, of a wed woman in her fidelity and devotion to

4 Война на Северном Кавказе смещается в Дагестан и КБР, (11 March 2011); available at http://adjaria.kavkaz-uzel.ru/articles/182170/. [Author: please provide title in English as well, and also the title of the publication, in italics, before the date of publication.] 
her husband and his clan, and that of a man in his courage, ability to avenge humiliation, and to ensure a dignified livelihood and protection for his family and clan members. ${ }^{5}$

Importantly, as it was the earliest part of the North Caucasus to embrace the Muslim religion in the seventh and eighth centuries, Dagestan has historically been regarded as the cradle of Islam in the region. Notwithstanding the often fierce attacks by the atheist Soviet state against Islam, religiosity is still widespread across all strata of Dagestani society. Islam - and more precisely Sufi Islam, with its locally most common Naqshbandi and Shazali tariqahs, or paths - has historically played a crucial role both as a symbol of self-identification for ordinary Dagestanis, and as an element of tradition in their daily lives, and hence as a source of legitimization of public activity. Accordingly, the scope of the religious revival that hit the North Caucasus (along with other parts of the post-Soviet space) in the early 1990s was felt most strongly in Dagestan, where hundreds of new mosques were built across the country. While the vast majority of ordinary Dagestanis turned to the traditionalist (Sufi) religion in that era of social turmoil and economic uncertainty, when the Soviet Union was beginning to crumble, some of them embraced Salafi Islam, which has since come to be regarded as an alternative to the largely discredited Sufi clergy, with their close ties to the ruling elites. ${ }^{6}$

Another important factor in local politics is the republic's multiethnic character, as Dagestan is home to dozens of native ethnicities, making up one of the world's most diverse ethno-linguistic areas. As no ethnic group forms a majority, members of various Dagestani peoples and clans are involved in constant competition over the republic's limited resources (around 80-90 percent of the republic's budget consists of direct subsidies from Moscow), which is documented in the complicated system of republican and local-level power-sharing mechanisms. ${ }^{7}$ Albeit it is primarily latent, tension exists among members of various ethnic groups. Despite episodic excesses that periodically reoccur due to rather apolitical reasons, such as control over certain disputed areas, local authorities have so far managed to keep these conflicts at a low simmer. In fact, the Dagestani peoples are quite prone to nationalism. Even though

For more information on adat, local codes of honor, and the custom of blood feud practiced by the Chechens, Dagestanis, and some other North Caucasian peoples, see Emil Souleimanov, An Endless War: The Russian-Chechen Conflict in Perspective (Frankurt am Main: Peter Lang, 2007), 24-39.

6 For more information on the Salafi-Sufi split and the radicalization of Islam in local socities, see Aleksey Malashenko, Islamskie orientiry Severnogo Kavkaza (Moscow: Gendalf, 2001), 104-126.

7 Kevin Daniel Leahy, 'North Caucasian Rebels' Economic Policy Defined by Conventionality and Wishful Thinking," The Central Asia-Caucasus Institute Analyst (2 February 2011). 
they live side by side, intermarriage is uncommon among members of distinct ethnic groups. Last but not least, Dagestan's corruption, clientelism, and nepotism are appalling, even by the already low standards in the Caucasus, with an unemployment rate reaching 80 percent among youth. This mountainous republic, with little agricultural land and almost no industry, was traditionally one of the poorest in the Russian federation. ${ }^{8}$

Fifteen years ago, there was hardly any talk about the presence of an Islamist insurgency in Dagestan, and even a decade ago its manifestations were extremely rare. Since then, however, it has been increasing dramatically. Although some Dagestani communities were the first in the North Caucasus to embrace Salafism in the beginning of the 1990s, the failed incursion of the united Dagestani-Chechen jihadist insurgents to Western Dagestan in August 1999 largely discredited the ideology across the republic. ${ }^{9}$ What has happened since then? First, since "Islamist terrorism" was widely recognized as a primary threat to national security in 1999-2001, thousands of mostly young Dagestanis who have been accused of terrorism and "Wahhabism" have been taken into custody by local authorities, where they were often subjected to Soviet-style interrogation. Deep religiosity has been considered especially suspicious by the authorities, which have been waging a full-scale war against real and alleged "Wahhabis" and their sympathizers. Yet for many undereducated, underpaid, and corrupt policemen operating with near-total impunity, capturing people for ransom has provided a reliable source of income. As the authorities have lacked sufficient evidence to put alleged "Wahhabis" in jail, these men were eventually set free following a few months of torture. Many of them never made peace with what was done to them in prison, and have turned to violence to retaliate for the humiliation they suffered. In cases where was killed or seriously wounded, their brothers, sons, or cousins have often pledged oaths to take revenge for the sake of family honor.

As it is difficult for individuals to combat government forces on their own, many young Dagestanis have joined the insurgent movement in the mountains, where they were exposed to the tenets of Salafism. The adoption of a common ideology of resistance has cemented the insurgency, shaping specific (if now rather de-individualized) goals, such as the establishment of an Islamic state independent from Moscow, and targets, mainly the Russian occupiers and their Dagestani "marionettes." The collective memory of the Dagestani peoples draws upon the notion of age-old, anti-colonial (i.e., anti-Russian) resistance. Fighting local renegades is an even more important task..$^{10}$

Mark Kramer, "Prospects for Islamic Radicalism and Violent Extremism in the North Caucasus and Central Asia", PONARS Eurasia Memo No. 28 (August 2008).

$9 \quad$ See Malashenko, Islamskie orientiry Severnogo Kavkaza,106.

10 An interesting insight into the rhetoric of North Caucasian jihadists is presented at "Imarat Kavkaz. Ogon sviashchennogo jihada" ["The Caucasus Emirate. The Fire of Holy Jihad"] (1 May 2011); available at http://www.kavkazcenter.com/russ/content/2011/05/01/81196.shtml. 
Likewise, many Dagestanis have joined the insurgency in protest a wide range of societal ills, including corruption, erosion of traditional values, and a lack of professional opportunities, as well as out of a desire for a better, Islamic future for their homeland. Most importantly, membership in Jihadist groups (jamaats) has helped individual combatants to overcome ethnic, sectarian, and clan-based loyalties, forging an unprecedented sense of social solidarity based on religion. Thus, the ideologization of resistance has evolved side by side with the politicization of violence.

As a result, a regular civil war is now underway in Dagestan. Approximately 2500 young Dagestanis are believed to be involved in the insurgency, which makes up at least a half of all North Caucasian combatants. ${ }^{11}$ Yet their numbers grow as more and more desperate youngsters join their ranks. Unlike neighboring Chechnya, with its "normalized" public space, insurgents rely on sympathy and support from ordinary Dagestanis who are antagonized by both corrupt local authorities and increasingly violent and indiscriminate police forces. While many Chechens have postponed revenge until "better times" in order to avoid reprisals, the quest to avenge wrongs through violence is ongoing daily in Dagestan, where the insurgency has expanded from areas dominated by the Avars, Dargins, and Laks to the Lezgi-dominated south and Kumyk east. Moreover, in some areas of Dagestan local authorities as well as businesses have become targets of racketeering by insurgents. To survive physically, they have to pay those they are supposed to be fighting, something unheard of in contemporary Chechnya.

\section{Kabardino-Balkaria}

Until quite recently, the Northwest Caucasus has been considered rather immune to the manifestations of militant Islamism. Indeed, unlike the ethnic autonomous areas of the Northeast Caucasus - i.e. Dagestan, Ingushetia, and Chechnya - these tiny republics with less than a million (Kabardino-Balkaria) and a half a million (Karachay-Cherkessia) inhabitants underwent a process of considerable Westernization and secularization during the seven decades of Soviet rule. Just as important, their small populations contain significant percentages of ethnic Russians. The local societies in these regions also lack what provides for swift and initially not necessarily politically-motivated mobilization in the more traditionally restive areas Northeast Caucasus - a prevalence of a highly traditional social structure, most importantly tribalism, customs of blood feud, and a strong role of Islam in the public and private sphere.

11 Author's personal interviews with the officers of the Makhachkala detachment of antiterrorist forces of the Dagestani Ministry of Interior, Makhachkala, May 2010. 
Yet life in both "dual" republics is marked by considerable tension between representatives of Turkic (Karachay, Balkar) and Adyghe (Cherkess, Kabardey, Abaza) groups that does not confine itself only to the nationalist pamphlets of local (pseudo)historians. Economic and political power is concentrated virtually entirely in the hands of demographically dominant Kabardians and Karachays in their respective republics, causing permanent discontent on the part of minority groups that sees themselves as discriminated against. Following centuries of forced migrations implemented by Russian authorities in an attempt to pacify the region, both groups also clash over some disputed territories. ${ }^{12}$

As a result, ethno-nationalist divisions seemed to be the predominant, if not single, ideological factor in the Northwest Caucasus just a decade ago. Yet the North Caucasus-style hunt for real and alleged "Wahhabis" that started in 1999-2001 and intensified during the desperate Nalchik attack of 2005 led by the first generation of local insurgents has led to the deepening "jihadization" of political opposition, with religion replacing ethnic identification as a main driver of division. ${ }^{13}$ The ongoing process has been fueled by the strong desire of local youths to distance themselves from the mentioned Turkic-Adyghe split, put an end to the power of corrupted elites, retaliate against the indiscriminate activities of local police, and in the best case scenario also achieve the establishment of an independent Islamic state in the North Caucasus.

The ongoing deterioration of the security situation in Kabardino-Balkaria testifies to the long-term inability of local authorities to effectively combat terrorism, even though, given the local peculiarities, that task might have been the easiest in this particular part of the North Caucasus. Like elsewhere in the region, brutal and usually unprofessional efforts on the part of local security forces to rid the country of "Wahhabis" have only contributed to strengthening the Islamist insurgency. ${ }^{14} \mathrm{In}$ both the Dagestan and Kabardino-Balkaria cases, what is now considered an Islamist insurgency is a largely homegrown phenomenon.

In fact, the main concern of the current president, Arsen Kanokov, and his close associates is widely believed by locals to be making money, and his efforts to maximally concentrate political and economic power under his authority are seen as being directed solely to this end. Intriguingly, following his inauguration in 2005, Kanokov, an ethnic Kabardey, made sure that revenues from the lucrative tourist business in the Elbrus area that had been earlier conceded to the Balkar minority by his predecessor

12 Балкарцы и кабардинцы: Извечный спор за землю, (13 October 2009); available at http://www.caucasustimes.com/article.asp?id=20128. [Author: please provide title in English, and the title of the publication where it appeared, in italics, before the date.]

13 See, for instance, Gordon M. Hahn, "The Jihadi Insurgency and the Russian Counterinsurgency in the North Caucasus," Post-Soviet Affairs 24:1 (January-March 2008): 1-39.

14 Ibid. 
(another Kabardey, Valery Kokov) were directed to the Kabardeys, which further infuriated the Balkars. Corruption is rampant in the republic, and positions in state administration are sold nearly openly, or are delivered to loyalists, with the role of the political opposition being reduced to zero. To establish any business, locals have to periodically pay off authorities.

In this situation, the Islamist militants are regarded by some as representing the only real opposition to the extremely unpopular regime. Regardless of the authorities' lasting anti-Salafi rhetoric, according to a recent survey, 39 percent of the KabardinoBalkaria inhabitants have a positive attitude toward Salafism. ${ }^{15}$ Nationalist appeals are also of importance, shaping pro-insurgency sentiments that draw on traditions of anti-Russian resistance led by numerous Adyghe tribes in the nineteenth century. The cultural memory of these conflicts, in which hundreds of thousands perished or were expelled from the region, make up the cornerstone of Adyghe identity event today. For the young generation of nationalist Kabardeys, who face high unemployment rates and virtually no social prospects, a feeling of being ethnic kin to "tough guys" of their own group that are by no means "worse than the Chechens" also plays a role as they search for some guiding concept that would give shape to their lives. ${ }^{16}$ Likewise, in the case of the Karachay-Balkars, the memory of the bloody deportation of 1944 and the resulting hardships suffered by the group still persist. Moreover, the Turkic groups, who primarily inhabit the remote mountainous areas of the Great Caucasus, still hold to their traditional ways; Islamist mobilization is generally easier among them than among the more Westernized Adyghes, who are concentrated mostly in the lowlands. Contributing to the anti-regime, anti-Moscow, and anti-Russian animosity on the one hand, and to the forging of a sense of Turko-Adyghe solidarity on the other are also growing anti-Caucasian sentiments in Russia proper, where natives of the North Caucasus are increasingly treated as second-class citizens. All in all, recent developments have helped boost the local insurgents' motto: "Let's fight the Russians and their local puppets - they are our real enemies, as we are all Muslims and should not care about ethnicity." ${ }^{17}$

In this regard, Tsipinov's assassination is highly emblematic, as he advocated the revival of ethnic values among the Adyghe peoples, most notably the Adyghe Habze - the archaic and highly complex set of customary laws and codes of etiquette.

15 39\% опрошенных жителей Кабардино-Балкарии проявляют симпатии к ваххабизму, Caucasus Times (31 May 2010); available at http://www.caucasustimes.com/article. asp?language $=2 \&$ id $=20224$.

16 Author's personal interviews with the students of the Kabardino-Balkar State University, Nalchik, May 2010.

17 As quoted on the website of the local insurgents, http://www.djamaattakbir.com/2010/05/ blog-post_7687.html (15 May 2010). 
Tsipinov did not hesitate even to criticize the religion of Islam as an alien element of Adyghe identity, as well as assailing Karachay-Balkars as an inferior group visà-vis the cultivated and autochthonous Adyghe. While Tsipinov was viewed by the insurgents as a propagator of jahiliyyah, or pre-Islamic paganism, who also contributed to the further deepening of the Turko-Adyghe divide, the pro-regime mufti was renowned for his bold "anti-Wahhabi" statements. The attacks on the Baksan hydroelectric power plant in July 2010 and the more developed elements of the tourist infrastructure were carried out to deprive the regime of its revenues, and to gain earn broader support among the public, in an effort to show to whom the republic really belongs. ${ }^{18}$

Yet, the increasingly violent activities on the part of the local insurgents have also brought about significant opposition within Kabardino-Balkaria, most notably in liberal urban areas. A group calling itself the "Black Hawks" has been establishedallegedly by local inhabitants - to fight "Wahhabi terrorism" by their own means, although some observers believe they are an initiative of Russian intelligence. Most importantly, some Kabardey and Balkar intellectuals have been calling for the revival of the ancient custom of blood feud, since taking revenge against the relatives of the insurgents would in the eyes of its proponents contribute to the lessening of insurgent activities, a measure that has been practiced quite successfully in Chechnya and increasingly also Ingushetia and Dagestan. In response to the insurgents' increasingly frequent and lethal attacks on police outposts, the authorities have removed police units from the region altogether, are now speculating about establishing special militia units with the aim of fighting insurgents. ${ }^{19}$

\section{Conclusion}

The emblematic feature of the Dagestani insurgency has been its avalanche-like mobilization, provided for by the prevalence of traditional institutions in the Northeast Caucasus. Regardless of the death of some influential field commanders, most recently the emir Seyfullah, the movement will not be dismantled overnight, as individual fighters will continue to wage their wars of revenge. That, in turn, will bring about more reprisals from the local authorities, which will lead to the "Chechenization" of the conflict, as increasing numbers of Dagestanis will become involved in blood feuds. As in the case of Chechnya and Ingushetia, the Dagestani insurgency

18 На юге России взорвана гидроэлектростанция, Nezavisimaya Gazeta (21 July 2010).

19 For more detail, see Mairbek Vatchagayev, “Kabardino-Balkaria's 'Black Hawks': Grassroots Vigilantes or FSB Surrogates?” North Caucasus Analysis 12:1 (11 March 2011); available at http://www.jamestown.org/programs/nca/single/?tx_ttnews\%5Btt_news\%5D $=37637 \& \mathrm{cHash}=\mathrm{ae} 3 \mathrm{cc} 634236 \mathrm{aba} 4 \mathrm{e} 22 \mathrm{~b} 1268 \mathrm{c} 1 \mathrm{ee} 698 \mathrm{e} 8$. 
is at its core primarily not a political or religious phenomenon, even though it is organized along the lines of Salafi Islam. This is where its main strength lies. Unlike Chechnya, where the ordinary people have experienced two atrocious wars and whose vast majority is thus willing to accept peaceful life under any government, many Dagestanis are euphoric about the opportunity to square their accounts with the ones they truly resent. Yet imposing the kind of sultanistic authoritarian regime that has been established in Kadyrov's Chechnya in recent years would be a rather unfeasible task for ethnically heterogeneous Dagestan.

Additionally, particular jamaats are becoming increasingly mixed ethnically; they continue to be highly autonomous units, based on the principle of territorial, rather than ethnic, kinship, tending to act on their own, which makes them difficult to track down and combat. Yet they share a common idea of resistance, a strong desire for personal revenge, and a hated enemy. They have thus come to rely on increasing sympathy from native populations, which have always had a tradition of hospitality toward anti-state outlaws. As the war goes on, Dagestani insurgents enhance their skills in guerilla warfare, as well their awareness of trans-ethnic solidarity with their Dagestani, Chechen, Ingush, Balkar, and Cherkes brethren in arms. In the months and years to come, Dagestan is thus very likely to retain its standing as the epicenter of the North Caucasian insurgency.

As for the case of Kabardino-Balkaria, the recent increase of Islamist insurgency in this Northwest Caucasian autonomous region, where the potential for Jihadistmotivated civil unrest in the regional context has up to now been quite low, clearly illustrates the overall failure of the anti-terrorist efforts of both local and federal authorities. Not only do the ambitious economic plans of the newly established North Caucasian federal district seem to be out of touch with reality, ${ }^{20}$ but some areas of the republic have also recently fallen under the insurgents' partial control, as they have even begun to extort money from local businesses and intimidate officials. With its large areas of wooded mountains and gorges, the republic provides the perfect terrain for guerilla fighting.

Importantly, Kabardino-Balkaria borders the predominantly Muslim areas of the Digoron ethnic subgroup of Ossetians, who have also been radicalized recently due to being subjected to frequent cases of police discrimination within North Ossetia. Kabardey-Balkar jamaats have been improving their sense of transethnic, Muslim solidarity, consistently strengthening their ties with Digoron Ossetians and partially absorbing some communities, thereby establishing a strategic link between the Northwest Caucasus and the key Northeast Caucasian battlefields. That poses a serious

20 In this regard, the desire of Alexander Khloponin, the de facto head of the newly established (January 2010) North Caucasus Federal Disctrict to turn Kabardino-Balkaria and adjacent republics into a tourist paradise is worth mentioning. 
The QuARTERLy JournAL

danger to the security of the forthcoming Winter Olympic Games in Sochi in 2014, and holds the potential to further destabilize the situation in neighboring Karachayevo-Cherkessia. This development poses an additional threat through the presence of significant Cossack communities in both autonomous regions, predominantly in the Russian areas of Stavropol and Krasnodar. 


\section{Bibliography}

Genprokuror predlozhil zashishatsya ot terraktov samim [The Chief Executor has Proposed to Defend from Terrorist Attacks by Ourselves]. BBC.com (Russian version), 2001.

Hahn, Gordon M.. "The Jihadi Insurgency and the Russian Counterinsurgency in the North Caucasus." Post-Soviet Affairs 24, no. 1 (2008): 1-39.

Imarat Kavkaz. Ogon sviashchennogo jihada [The Caucasus Emirate. The Fire of Holy Jihad]., 2011.

Kramer, Mark. Prospects for Islamic Radicalism and Violent Extremism in the North Caucasus and Central Asia In PONARS Eurasia Memo., 2008.

Leahy, Kevin Daniel. North Caucasian Rebels' Economic Policy Defined by Conventionality and Wishful Thinking. The Central Asia-Caucasus Institute Analyst, 2011.

Malashenko, Aleksey. Islamskie orientiry Severnogo Kavkaza. Moscow: Gendalf, 2001.

Souleimanov, Emil. An Endless War: The Russian-Chechen Conflict in Perspective. Frankurt am Main: Peter Lang, 2007.

Ugroza terrorizma $v$ Rossii sokhranaetsya [The Terrorist Threat in Russia Remains]. Rosbalt.

Vatchagayev, Mairbek. "Kabardino-Balkaria's 'Black Hawks': Grassroots Vigilantes or FSB Surrogates?" North Caucasus Analysis 12, no. 1 (2011).

На юге России взорвана гидроэлектростанция. Nezavisimaya Gazeta (2010). 